\title{
New Protection Legislation round the World
}

\section{Colombia}

From October 1973 Colombia banned the hunting of jaguar, ocelot and all other cats, spectacled bear, otters and other Carnivora for any purpose whatever, banned the hunting and export of the spectacled caimans in the Orinoco (with a minimum size limit elsewhere), and banned commercial hunting of peccaries, boas, anacondas and all birds. There is reason to believe that caimans have been exported through the island of Curaçao (a free port) en route to Miami, with Curaçao given as the country of originthere are no caimans in Curaçao. It is expected that the US will put all Colombian crocodilians on the Endangered Species List, as requested by a group of university professors (see the February Oryx, page 302), which will be a big step towards stamping out this trade.

\section{Ghana}

The Ghana Government has passed an excellent Forest Protection Decree which makes it illegal to hunt, shoot, fish, set traps or snares, or poison water in any forest reserve. Penalties for infringement include a fine and up to 10 years imprisonment for a second offence. Moreover, the burden of proof that any forest produce was not taken illegally lies with the person in whose possession it was found.

\section{Peru}

In October 1973 Peru banned all hunting and capturing of spotted cats, puma, all monkeys, giant anteater, giant armadillo, giant otter, manatee and marsh deer in Peruvian Amazonia, and banned all trade in products of these species. Now that Peru, Colombia and Brazil all have similar legislation it should be possible to co-ordinate enforcement of the law and stop illegal traffic.

\section{Taiwan}

The Taiwan Government has prohibited the export of all wildlife and also the sale of all stuffed specimens. Moreover, the measures are being rigidly enforced. This news comes from a Taiwan resident, Dennis Poltlock, in a report to Philip Wayre, who recommended both measures in his report on Taiwan-see Oryx, May 1969.

\section{USA}

The USA has banned the import of exotic animals for pets since February this year. As Americans alone in 1972 bought 120 million wild animals this should have a drastic effect on a deplorable trade. The waste is of course enormous. As many as three quarters of animals, especially monkeys and birds, may die during capture or transit to the trader.

The US Bureau of Customs offers cash awards (up to $\$ 50,000$ ) for original information leading to the arrest of persons engaged in smuggling live animals.

Venezuela banned the export of all wildlife in April, 1973. 